\title{
29. NEOGENE PALEOCEANOGRAPHY OF THE NORWEGIAN SEA BASED UPON SILICOFLAGELLATE ASSEMBLAGE CHANGES IN ODP LEG 104 SEDIMENTARY SEQUENCES ${ }^{1}$
}

\author{
Paul F. Ciesielski and Susan M. Case ${ }^{2}$
}

\begin{abstract}
Silicoflagellate assemblages of ODP Leg 104 Neogene sequences are the basis of an interpretation of changes in the Neogene paleoenvironment of the Norwegian Sea. Fluctuations in the percentages of temperature and nutrient-sensitive taxonomic groups document major changes in sea-surface conditions. A brief, but distinct, cooling event occurred at 18.0-17.5 Ma which resulted in the disappearance of Naviculopsis. Following this early Miocene cooling a long period of increasing surface-water temperature occurred, leading up to a thermal high in the early middle Miocene (14.0 Ma). The early late Miocene (10.0-9.0 Ma) was distinctly cooler than the middle Miocene, but warmer than the remainder of the Neogene. Conditions between 13.0 and $10.0 \mathrm{Ma}$ are unrecorded because of a regional hiatus, which is the earliest evidence for an end to the more temperate and stable conditions of the early to middle middle Miocene. A major plunge in temperatures occurred between 8.5 and 7.4 Ma and during the remainder of the late Miocene and Pliocene; from 7.4 to $2.65 \mathrm{Ma}$ subpolar conditions prevailed. Silicoflagellates disappeared, except for sporadic occurrences, at $2.64 \mathrm{Ma}$ with the beginning of dominant glacial sedimentation. Biogenic opal is absent in sediments younger than $0.76 \mathrm{Ma}$, indicating the dominance of glacial conditions with extensive sea ice.
\end{abstract}

\section{INTRODUCTION}

The ODP Leg 104 sites in the Norwegian Sea were the first drilled since the Deep Sea Drilling Project (DSDP) Leg 38 (Talwani, Udintsev, et al., 1976) drilled a number of sequences in the Norwegian-Greenland Sea. Leg 38 sites were drilled discontinuously by rotary coring $(\mathrm{RCB})$, resulting in very incomplete recovery and often disturbed sequences poorly suited for detailed paleoceanographic studies. In contrast, Leg 104 sites were continously drilled using advanced piston core (APC) and extended core barrel (XCB) methods which minimize core disturbance. As a result, sedimentary sequences recovered by Leg 104 provide a unique opportunity to examine the paleoceanographic history of the Norwegian Sea.

This contribution interprets the history of surface-water mass characteristics where the Norwegian Current flows over the Vøring Plateau (Fig. 1). Changes in temperature and productivity of surface waters were inferred based upon quantitative fluctuations in the silicoflagellate taxon groups, some of which have well-defined paleoenvironmental affinities. The quantitative census of silicoflagellates from Sites 642, 643, and 644 (Ciesielski, Hasson, and Turner, this volume) forms the data base for this study and represents the only detailed quantitative census of Neogene silicoflagellate assemblages from north of the Arctic Circle.

Figure 2 shows the location of Leg 104 sites with respect to the Vøring Plateau. The three sites represent a transect through a portion of the Norwegian Current. At Site $644\left(66^{\circ} 40.7^{\prime} \mathrm{N}\right.$, $04^{\circ} 34.6^{\prime} \mathrm{E}, 1227 \mathrm{~m}$ ), the landward site, a $252.8-\mathrm{m}$ section of Pliocene-Quaternary sediments was drilled from the inner continental slope. Site $643\left(67^{\circ} 42.9^{\prime} \mathrm{N}, 01^{\circ} 02.0^{\prime} \mathrm{E}, 2753 \mathrm{~m}\right)$ forms the seaward end of the transect, located on the lower slope near the foot of the outer Vøring Plateau. Between these two sites lies Site $642\left(67^{\circ} 13.2^{\prime} \mathrm{N}, 02^{\circ} 55.8^{\prime} \mathrm{E}, 1277 \mathrm{~m}\right)$ on the outer Vøring Plateau. The latter two sites contain rich silicoflagellate assemblages throughout the lower Miocene to Pliocene.

\footnotetext{
${ }^{1}$ Eldholm, O., Thiede, J., Taylor, E., et al,, 1989. Proc. ODP, Sci. Results, 104: College Station, TX (Ocean Drilling Program).

21112 Turlington Hall, Department of Geology, University of Florida, Gainesville, FL 32611.
}

The paleoceanographic history of the Norwegian Sea had profound influences on the global deep-water masses and climatic conditions on the adjacent continental margin. The Norwegian Current is a continuation of the Gulf Stream system which follows the Norwegian continental margin carrying relatively warm surface waters to the northern polar basins. Leg 104 sites are located where the current is relatively narrow and welldefined (Fig. 1). Site 643 is the westernmost site; while still in the Norwegian Current, it is closest to polar water masses of the open Norwegian-Greenland Sea.

\section{METHODS}

The data base for this study is the quantitative census of silicoflagellates from the Neogene of Leg 104 sites by Ciesielski et al. (this volume). Census data were supplemented herein with assemblage counts from 12 additional samples from Hole $643 \mathrm{~A}$ to increase the sample density for this hole. The paleoceanographic interpretation of these census data is based upon collection of silicoflagellate species into meaningful taxonomic groups, whose paleoenvironmental affinities were interpreted through the environmental and biogeographic affinities of extant and/ or extinct taxa. The census data of Ciesielski et al. (this volume) were amassed into the following taxonomic groups: Dictyocha (extant), hexagonal Distephanus (extant), quadrate Distephanus (extinct), Bachmannocena (extinct), Corbisema (extinct), Naviculopsis (extinct), and Caryocha (extinct). Interpretation of the paleoenvironmental significance of each taxon group is presented in the following section. Percentages of each taxonomic group were calculated as a percent of the total silicoflagellate assemblage from each sample. Figures 3-8 show the percentage of each taxonomic group in samples from Hole 643A (Figs. 3-5) and Holes $642 \mathrm{C}$ and 642D (Figs. 6-8). Silicoflagellates are sparse in all but a few samples from Hole 644A; therefore, no figure is provided. Table 3 of Ciesielski et al. (this volume) provides assemblage census information for Hole 644A.

Sediment ages for each of the sites studied are also presented in Figures 3-8. Tables 1 and 2 provide selected biostratigraphic and paleomagnetic datums utilized to interpret the ages of these sequences. At the time of this submission, final diatom biostratigraphic results were not yet available but are expected to increase age control, particularly of the lower Miocene section. Major disconformities are shown by wavy lines. Shorter duration disconformities are suggested by the detailed biostratigraphic chapters of this volume, but are omitted because there is no uniformity of opinion by Leg 104 biostratigraphers as to their age, depth, and duration. In any case, these minor disconformities probably represent less time than is represented between most of the studied samples. 


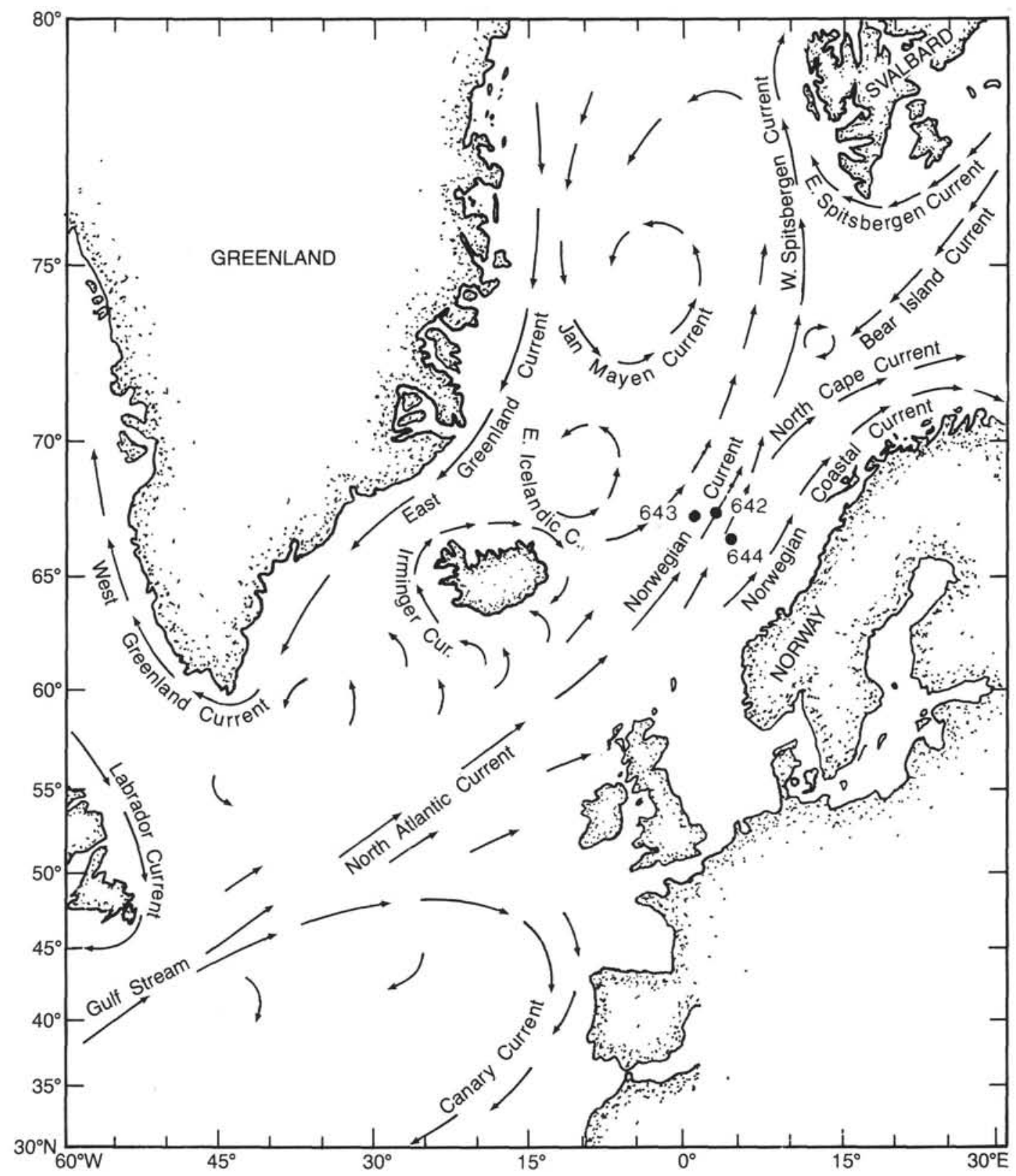

Figure 1. Present-day surface current patterns in the Norwegian-Greenland Sea (Kellogg, 1975, 1976). Leg 104 sites are shown.

\section{PALEOENVIRONMENTAL SIGNIFICANCE OF TAXONOMIC GROUPS}

Neogene silicoflagellate assemblages are dominated by a limited number of genera, the most abundant of which include: Dictyocha, Distephanus, Caryocha, Corbisema, Naviculopsis, and Bachmannocena. Distribution and abundances of Dictyocha and Distephanus, the only extant genera, are very much influenced by temperature. Because of the large number of studies of silicoflagellate biogeography and abundance, the paleoenvironmental affinities of extinct genera are now becoming relatively well-defined. As a consequence, there is an increased usage of silicoflagellates to both define surface-water paleotemperature trends (Mandra, 1969; Ciesielski and Weaver, 1974; Bukry, 1981a, 1983, 1985a, 1985b, 1985c, 1987; and others), and to interpret productivity and upwelling changes (Bukry, 1986). Discussed below are the inferred paleoenvironmental af- finities of seven taxonomic groups of silicoflagellates used to interpret the Neogene paleoenvironmental history of surface waters where the Norwegian Current passes over the Vøring Plateau.

\section{Dictyocha and Hexagonal Distephanus}

Dictyocha and hexagonal Distephanus are the dominant silicoflagellate taxon groups for most of the Pliocene and Quaternary. The biogeographic distribution of extinct and extant species of each group reveals a distinct temperature control on their distribution during the Pliocene-Quaternary, with Dictyocha most abundant in temperate to tropical regions (Bukry 1985b; Mandra, 1969; Martini 1971; and others) and hexagonal Distephanus dominant over Dictyocha in subpolar to polar regions (Ciesielski, 1974, 1975; Shaw and Ciesielski, 1983; and others). Because both groups account for more than $95 \%$ of the Pliocene-Quaternary silicoflagellate assemblages, these temperature 


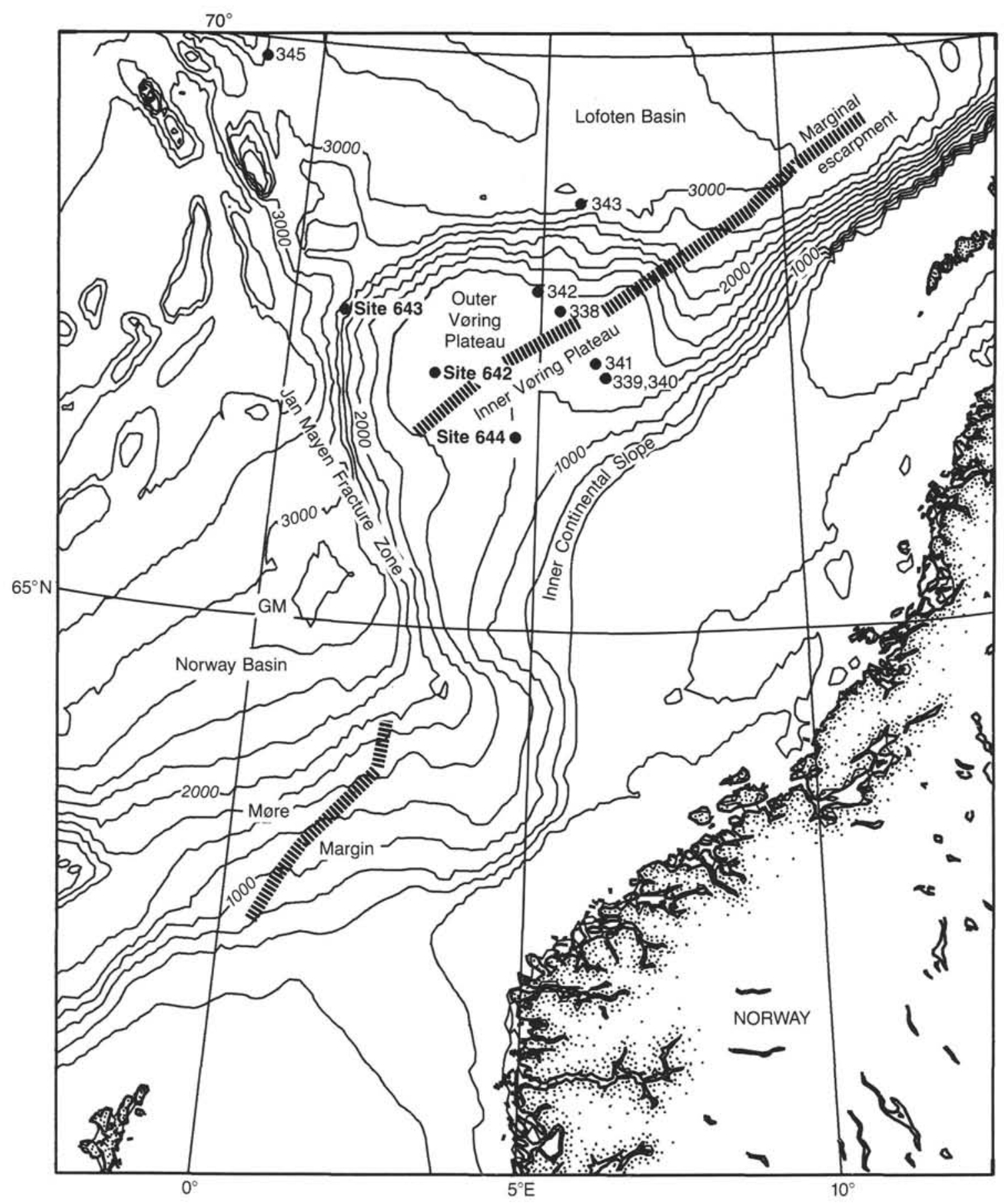

Figure 2. Bathymetry and location of ODP Leg 104 and DSDP Leg 38 sites on the Vøring Plateau. Contour interval: $250 \mathrm{~m}$.

preferences allow for an unambiguous interpretation of relative paleotemperatures based on their abundances, assuming little change in their paleotemperature affinity.

The warm vs. cool temperature preferences for Dictyocha and hexagonal Distephanus have been noted for some time (since at least Gemeinhardt, 1934). Fluctuations in the abundance of individual species or ratios of Dictyocha to Distephanus were utilized by a number of researchers to interpret changes in surface-water temperature (Mandra, 1969; Martini, 1971; Ciesielski, 1974; Ciesielski and Weaver, 1974; and others).
Further, Ciesielski (1974) quantified the relationship between the abundances of Dictyocha and hexagonal Distephanus in antarctic and subantarctic surface sediments and the overlying mean annual surface-water temperatures. Ratios of these taxonomic groups were established between Australia and Antarctica where mean annual surface waters range from $1^{\circ}$ to $13^{\circ} \mathrm{C}$. This study revealed that ratios of Dictyocha to hexagonal Distephanus range from 10:1 to $35: 1$ in surface sediments where overlying mean annual temperatures are $13^{\circ} \mathrm{C}$, and decrease to $1: 1.2$ at $7^{\circ} \mathrm{C}$. Hexagonal Distephanus becomes increasingly dominant 
Table 1. Paleomagnetic and selected microfossil datums utilized to interpret the ages of silicoflagellate assemblage changes in Hole 643A. Identified are the datums, datum ages and references, sub-bottom depth (in meters) of datums, and samples between which the datums were identified.

\begin{tabular}{|c|c|c|c|}
\hline Datum & Age & Depth & $\begin{array}{l}\text { Core and section the } \\
\text { datum occurs between }\end{array}$ \\
\hline Brunhes/Matuyama & $0.73(1)$ & 26.56 & $4 \mathrm{H}-2,56 \mathrm{~cm} / 4 \mathrm{H}-2,96 \mathrm{~cm}$ \\
\hline Top Jaramillo & 0.91 (1) & 29.95 & $4 \mathrm{H}-4,97 \mathrm{~cm} / 4 \mathrm{H}-4,131 \mathrm{~cm}$ \\
\hline Base Jaramillo & $0.98(1)$ & 31.46 & $4 \mathrm{H}-5,97 \mathrm{~cm} / 4 \mathrm{H}-5,135 \mathrm{~cm}$ \\
\hline Top Olduvai & $1.66(1)$ & 49.71 & $6 \mathrm{H}-5,27 \mathrm{~cm} / 6 \mathrm{H}-5,55 \mathrm{~cm}$ \\
\hline Base Olduvai & $1.88(1)$ & 54.34 & $7 \mathrm{H}-1,135 \mathrm{~cm} / 7 \mathrm{H}-2,23 \mathrm{~cm}$ \\
\hline Disconformity & \multicolumn{2}{|l|}{$\sim 68.33 \mathrm{~m}$} & \\
\hline $\mathrm{C} 4 \mathrm{~N} / \mathrm{C} 4 \mathrm{R}$ & $7.41(1)$ & 69.78 & $9 \mathrm{H}-4,137 \mathrm{~cm} / 9 \mathrm{H}-5,25 \mathrm{~cm}$ \\
\hline $\mathrm{C} 4 \mathrm{R} / \mathrm{C} 4 \mathrm{AN}$ & 7.90 (1) & 83.01 & $10 \mathrm{H}-1,137 \mathrm{~cm} / 10 \mathrm{H}-2,25 \mathrm{~cm}$ \\
\hline C4AN/C4AR & 8.50 (1) & 91.96 & $11 \mathrm{H}-1,95 \mathrm{~cm} / 11 \mathrm{H}-1,135 \mathrm{~cm}$ \\
\hline \#FAD N. acostaensis & *10.4 (4) & 99.96 & $11 \mathrm{H}-6,130 \mathrm{~cm}$ \\
\hline \#FAD Rhizosolenia barboi & $11.2(6)$ & 94.26 & $11 \mathrm{H}-5,72 \mathrm{~cm} / 11 \mathrm{H}-6,70 \mathrm{~cm}$ \\
\hline \multicolumn{4}{|l|}{ Disconformity } \\
\hline \#LAD Coscinodiscus plicatus & $* 7.3(7)$ & 94.26 & $11 \mathrm{H}-5,72 \mathrm{~cm} / 11 \mathrm{H}-6,70 \mathrm{~cm}$ \\
\hline \#LAD D. lauta & $+8.5-8.7(9)$ & 94.26 & $11 \mathrm{H}-5,72 \mathrm{~cm} / 11 \mathrm{H}-6,70 \mathrm{~cm}$ \\
\hline LAD C. lewisianus & $* 12.9(6)$ & 101.40 & $11 \mathrm{H}, \mathrm{CC} / 12 \mathrm{H}-2,70 \mathrm{~cm}$ \\
\hline LAD $D$. nicobarica & $13.2(6)$ & 100.01 & $11 \mathrm{H}-6,72 \mathrm{~cm} / 12 \mathrm{H}-1,70 \mathrm{~cm}$ \\
\hline FAD Coscinodiscus plicatus & $13.9(3)$ & 103.25 & $12 \mathrm{H}-2,72 \mathrm{~cm} / 12 \mathrm{H}-3,70 \mathrm{~cm}$ \\
\hline FAD D. hustedtii (main) & $13.9(3)$ & 109.51 & $13 \mathrm{H}-1,69 \mathrm{~cm} / 12 \mathrm{H}-6,72 \mathrm{~cm}$ \\
\hline FAD D. hustedtii (isolate) & $14.2(3)$ & 118.99 & $13 \mathrm{H}-6,69 \mathrm{~cm} / 14 \mathrm{H}-1,70 \mathrm{~cm}$ \\
\hline FAD D. punctata hustedtii & $13.7(3)$ & 122.26 & $14 \mathrm{H}-2,72 \mathrm{~cm} / 14 \mathrm{H}-3,70 \mathrm{~cm}$ \\
\hline LAD Cestodiscus peplum & $* 14.10(2)$ & 123.76 & $14 \mathrm{H}-3,72 \mathrm{~cm} / 14 \mathrm{H}-4,70 \mathrm{~cm}$ \\
\hline FAD D. hyalina & $15.0(6)$ & 126.50 & $14 \mathrm{H}-5,72 \mathrm{~cm} / 14 \mathrm{H}-6,70 \mathrm{~cm}$ \\
\hline FAD Denticulopsis lauta & $16.1(6)$ & 135.04 & $15 \mathrm{H}-4,127 \mathrm{~cm} / 15 \mathrm{H}-5,71 \mathrm{~cm}$ \\
\hline FAD Cestodiscus peplum & $* 16.4(6)$ & 135.04 & $15 \mathrm{H}-4,127 \mathrm{~cm} / 15 \mathrm{H}-5,71 \mathrm{~cm}$ \\
\hline FAD Actinocyclus ingens & $16.8(5)$ & 204.35 & $22 \mathrm{X}-5,71 \mathrm{~cm} / 23 \mathrm{X}-2,70 \mathrm{~cm}$ \\
\hline LAD Triceratium pileus & $17.6(3)$ & 249.51 & $27 \mathrm{X}-2,72 \mathrm{~cm} / 27 \mathrm{X}-6,70 \mathrm{~cm}$ \\
\hline LAD Naviculopsis & $17.35-17.6(12)$ & 259.31 & $28 \mathrm{X}-2,72 \mathrm{~cm} / 28 \mathrm{X}-6,70 \mathrm{~cm}$ \\
\hline LAD Thalassiosira spinosa & $* 17.9(3)$ & 268.36 & $29 \mathrm{X}-2,72 \mathrm{~cm} / 29 \mathrm{X}-5,70 \mathrm{~cm}$ \\
\hline
\end{tabular}

(1) Paleomagnetic polarity record by Bleil (this volume), identification of Chrons by Ciesielski based upon diatom and silicoflagellate biostratigraphy, age of paleomagnetic boundaries after Berggren et al., 1985. (2) Burckle, 1978. (3) Barron, 1985a. (4) Datum defined by Spiegler and Jansen, this volume; age from Berggren et al., 1985. (5) Barron, 1985b. (6) Barron et al., 1985. (7) Barron unpublished data cited in Barron, 1985a. (8) Burckle et al., 1982. (9) Ciesielski, 1983. (10) Burckle oral communication to Barron, 1982. (11) Ciesielski et al., this volume. (12) Correlation of Bukry (1985) to Barron (1985). + Absolute age date; Ciesielski, 1983. * Direct correlation to the paleomagnetic time scale. \# Lower or upper range truncated by hiatus.

from the Antarctic Convergence southward; ratios of Dictyocha to hexagonal Distephanus are $<0.5$ where surface waters are $<$ $4^{\circ} \mathrm{C}$. Close to the Antarctic continent where mean annual surface waters are $1^{\circ}$ to $2^{\circ} \mathrm{C}$, Dictyocha is virtually absent.

Paleotemperatures were inferred from the abundances of Dictyocha and hexagonal Distephanus in Pliocene-Quaternary sediments from the Norwegian Sea where these taxa dominate the assemblage. Miocene abundances were not treated in a similar manner because other groups of silicoflagellates are major elements of the assemblage, and their influence on Dictyocha and hexagonal Distephanus abundances, as well as on temperature relationships, remains uncertain.

There are exceptions to the warm and cool surface-water preference of extant Dictyocha and Distephanus. Dictyocha mandrai occurs in high percentages in the high-latitude North Pacific (Poelchau, 1974) and Distephanus pulchra occurs at high abundance in low-latitude eutrophic environments (Takahashi, 1987). Although neither of these species were encountered in the present study, it is possible that some species of Dictyocha and Distephanus deviate from the predicted paleoenvironmental affinity. Since such deviations probably are the exception rather than the rule, they are not thought to significantly alter the interpretations presented here.

\section{Quadrate Distephanus}

Quadrate forms of Distephanus were common throughout most of the lower and middle Miocene; however, they largely disappeared during the late Miocene with a few survivors lingering into the Pliocene. Bukry (1981a) considered the group to have temperate affinities based upon its abundance in DSDP sites in the Pacific between $40^{\circ}$ and $23^{\circ} \mathrm{S}$.

Studies reveal that hexagonal Distephanus obtained continuing dominance over quadrate Distephanus earlier in the Antarctic and Subantarctic regions (early Miocene) than in the lower latitudes (middle late Miocene) (Bukry, 1985). This difference supports the conclusion that quadrate Distephanus were more temperate, decreased in abundance, and migrated out of polar waters with progressive Neogene cooling. Prior to the Neogene cooling of high-latitude surface waters, quadrate Distephanus often equaled or dominated hexagonal Distephanus (Bukry, 1985).

\section{Bachmannocena}

Bukry (1986) reviewed variations in the abundance of several species of Bachmannocena in approximately 50 DSDP sites from the Atlantic, Pacific, Indian Ocean, and Southern Ocean. These species include $B$. diodon diodon, $B$. diodon nodosa, $B$. circulus v. apiculata, and $B$. dumitricae-all common species in Leg 104 sites. The abundance variations of these species in the middle Miocene to lower Pliocene of these sites provide evidence for these species being most abundant in oceanic regions where cool water currents occur in nutrient-rich upwelling regions, regardless of latitude. Examples of nutrient-rich regions 
Table 2. Paleomagnetic and selected microfossil datums utilized to interpret the ages of silicoflagellate assemblage changes in Holes 642C and 642D. Identified are the datums, datum ages and references, sub-bottom depth (in meters) of datums, and samples between which the datums were identified.

\begin{tabular}{|c|c|c|c|}
\hline Datum & Age & Depth & $\begin{array}{l}\text { Core and section the } \\
\text { datum occurs between }\end{array}$ \\
\hline Brunhes/Matuyama & $0.73(1)$ & 33.57 & $5 \mathrm{H}-1,32 \mathrm{~cm} / 5 \mathrm{H}-1,101 \mathrm{~cm}$ \\
\hline Top Jaramillo & $0.91(1)$ & 39.57 & $5 \mathrm{H}-5,33 \mathrm{~cm} / 5 \mathrm{H}-5,101 \mathrm{~cm}$ \\
\hline Base Jaramillo & $0.98(1)$ & 42.97 & $6 \mathrm{H}-1,119 \mathrm{~cm} / 6 \mathrm{H}-2,45 \mathrm{~cm}$ \\
\hline Top Olduvai & $1.66(1)$ & 51.05 & $6 \mathrm{H}-6,118 \mathrm{~cm} / 7 \mathrm{H}-1,110 \mathrm{~cm}$ \\
\hline Base Olduvai & $1.88(1)$ & 53.92 & $7 \mathrm{H}-2,113 \mathrm{~cm} / 7 \mathrm{H}-3,41 \mathrm{~cm}$ \\
\hline Disconformity & & & $7 \mathrm{H}-4,114 \mathrm{~cm} / 8 \mathrm{H}-1,40 \mathrm{~cm}$ \\
\hline \#LAD Distephanus jimlingii & $2.90(11)$ & 61.05 & $9 \mathrm{H}-2,103 \mathrm{~cm} /$ Barren zone \\
\hline Gauss/Gilbert & $3.40(1)$ & 65.00 & $\sim 10 \mathrm{H}-1,150 \mathrm{~cm}$ \\
\hline Gilbert/C3AN & $5.35(1)$ & 79.76 & $11 \mathrm{H}-5,41 \mathrm{~cm} / 11 \mathrm{H}-5,111 \mathrm{~cm}$ \\
\hline FAD $T$. oestrupii & $* 5.35(2)$ & 82.73 & $11 \mathrm{H}-5,126 \mathrm{~cm} / 12 \mathrm{H}-2,120 \mathrm{~cm}$ \\
\hline $\mathrm{C} 3 \mathrm{AN} / \mathrm{C} 3 \mathrm{AR}$ & $5.89(1)$ & 104.51 & $14 \mathrm{H}-2,112 \mathrm{~cm} / 14 \mathrm{H}-3,40 \mathrm{~cm}$ \\
\hline FAD Nitzschia reinholdii & $* 6.50(2)$ & 112.24 & $15 \mathrm{H}-4,127 \mathrm{~cm} / 15 \mathrm{H}-5,125 \mathrm{~cm}$ \\
\hline FAD Nitzschia miocenica & $\bullet 6.8(2)$ & 112.24 & $15 \mathrm{H}-4,127 \mathrm{~cm} / 15 \mathrm{H}-5,125 \mathrm{~cm}$ \\
\hline $\mathrm{C} 3 \mathrm{AR} / \mathrm{C} 4 \mathrm{~N}$ & $6.70(1)$ & 118.41 & $15 \mathrm{H}-5,110 \mathrm{~cm} / 15 \mathrm{H}-6,35 \mathrm{~cm}$ \\
\hline LAD Coscinodiscus yabei & $* 7.5(2)$ & 127.01 & $16 \mathrm{H}-4,127 \mathrm{~cm} / 16 \mathrm{H}-5,125 \mathrm{~cm}$ \\
\hline LAD C. plicatus & $* 7.3(7)$ & 128.51 & $16 \mathrm{H}-6,125 \mathrm{~cm} / 16 \mathrm{H}-5,127 \mathrm{~cm}$ \\
\hline \#FAD $R$. barboi (temp.) & $11.2(6)$ & 128.51 & $16 \mathrm{H}-6,125 \mathrm{~cm} / 16 \mathrm{H}-5, .27 \mathrm{~cm}$ \\
\hline \multicolumn{4}{|l|}{ Disconformity } \\
\hline \#LAD D. lauta & $+8.5-8.7(9)$ & 130.05 & $16 \mathrm{H}-6,127 \mathrm{~cm} / 17 \mathrm{H}-1,125 \mathrm{~cm}$ \\
\hline C4AN/C4AR & $8.5(1)$ & 132.27 & $17 \mathrm{H}-2,29 \mathrm{~cm} / 17 \mathrm{H}-2,125 \mathrm{~cm}$ \\
\hline C4AR/C5N & $8.92(1)$ & 133.64 & $17 \mathrm{H}-3,38 \mathrm{~cm} / 17 \mathrm{H}-3,90 \mathrm{~cm}$ \\
\hline \#FAD N. acostaensis & $* 10.4(4)$ & 158.42 & $19 \mathrm{H}-\mathrm{CC}, 49 \mathrm{~cm}$ \\
\hline \#FAD C. plicatus & $13.9(3)$ & 158.77 & $19 \mathrm{H}-5,128 \mathrm{~cm} / 20 \mathrm{H}-2,125 \mathrm{~cm}$ \\
\hline \#FAD C. yabei & 13.7() & 158.77 & $19 \mathrm{H}-5,128 \mathrm{~cm} / 20 \mathrm{H}-2,125 \mathrm{~cm}$ \\
\hline \multicolumn{4}{|l|}{ Disconformity } \\
\hline \#LAD C. coscinodiscus & $* 10.7(6)$ & 158.77 & $19 \mathrm{H}-5,128 \mathrm{~cm} / 20 \mathrm{H}-2,125 \mathrm{~cm}$ \\
\hline \#LAD C. lewisianus & *12.90(6) & 158.77 & $19 \mathrm{H}-5,128 \mathrm{~cm} / 20 \mathrm{H}-2,125 \mathrm{~cm}$ \\
\hline FAD D. punctata hustedtii & $13.7(3)$ & 177.78 & $21 \mathrm{H}-5,128 \mathrm{~cm} / 22 \mathrm{H}-2,125 \mathrm{~cm}$ \\
\hline FAD D. hustedtii (main) & $13.9(3)$ & 181.77 & $22 \mathrm{H}-2,128 \mathrm{~cm} / 22 \mathrm{H}-4,125 \mathrm{~cm}$ \\
\hline FAD $D$. hyalina & $15.0(6)$ & 185.15 & $22 \mathrm{H}-4,128 \mathrm{~cm} / 23 \mathrm{H}-2,125 \mathrm{~cm}$ \\
\hline FAD Denticulopsis lauta & $16.1(6)$ & 193.37 & $23 \mathrm{H}-5,128 \mathrm{~cm} / 24 \mathrm{H}-2,125 \mathrm{~cm}$ \\
\hline FAD Actinocyclus ingens & $16.8(5)$ & 199.73 & $2 X-5,127 \mathrm{~cm} / 3 \mathrm{X}-2,125 \mathrm{~cm}$ \\
\hline FAD C. coscinodiscus & $* 17.3(3)$ & 212.98 & $3 \mathrm{X}-5,127 \mathrm{~cm} / 4 \mathrm{X}-2,12 \mathrm{~cm}$ \\
\hline LAD Naviculopsis & $* 17.35-17.6(12)$ & 232.71 & $6 \mathrm{X}-2,127 \mathrm{~cm} / 6 \mathrm{X}-4,115 \mathrm{~cm}$ \\
\hline Occ. N. maleinterpretaria & $<18.8(3)$ & 267.00 & $9 \mathrm{X}-\mathrm{CC}$ \\
\hline
\end{tabular}

(1) Paleomagnetic polarity record by Bleil (this volume), identification of Chrons by Ciesielski based upon diatom and silicoflagellate biostratigraphy, age of paleomagnetic boundaries after Berggren et al., 1985. (2) Burckle, 1978. (3) Barron, 1985a. (4) Datum defined by Spiegler and Jansen, this volume; age from Berggren et al., 1985. (5) Barron, 1985b. (6) Barron et al., 1985. (7) Barron unpublished data cited in Barron, 1985a. (8) Burckle et al., 1982. (9) Ciesielski, 1983. (10) Burckle oral communication to Barron, 1982. (11) Ciesielski et al., this volume. (12) Correlation of Bukry (1985) to Barron (1985). + Absolute age date; Ciesielski, 1983. * Direct correlation to the paleomagnetic time scale; \# Lower or upper range truncated by hiatus. Occ. = occurrence.

where peak abundances of Bachmannocena were noted in the summary by Bukry (1986) include:

Peru Current-Equatorial Upwelling: Holes 157 (34\%), 321 $(13 \%)$ 572A (12\%), 503A (40\%). Baja Mexico, Coastal Upwelling: Hole $470(45 \%)$. Antarctic Convergence Zone: Hole 329 (92\%), 278 (48\%). Subtropical Convergence, South Pacific: Holes $594(95 \%)$. Walvis Ridge (topographic upwelling): Hole 362 (19\%). Rockall Plateau: Holes 554A (37\%), $552(22 \%)$. Vøring Plateau: Hole 338 (34\%). Reykjanes Ridge, SE of Iceland: Holes $407(18 \%), 408(41 \%)$.

Because the highest percentages of Bachmannocena in Leg 104 samples are dominated by the aforementioned species, we infer higher abundances of this genus to be indicative of cool to temperate surface waters with a rich nutrient supply caused by upwelling or strong vertical mixing of surface waters. The paleoenvironmental affinities of other Bachmannocena species are less certain. They were, however, not as significant a component of the silicoflagellate assemblage as the previously named species were in the upper middle to upper Miocene.

\section{Corbisema}

The genus Corbisema became extinct during the middle Miocene at approximately $13 \mathrm{Ma}$ (Bukry, 1987). The species $C$. triacantha is the principal representative of this genus in Leg 104 sequences, except for the occurrence of $C$. flexuosa in the basal portion of Hole 642D. While most silicoflagellates are relatively resistant to dissolution, $C$. triacantha is thin-walled and more susceptible to dissolution than the other taxonomic groups considered here. As a result, variations in the abundance of Corbisema may be, in part, a consequence of significant dissolution.

Corbisema is most closely related to Dictyocha and has been considered a warm-water genus based upon its stratigraphic range and distribution (Bukry, 1981b). The greatest abundance of the genus occurred during the period of maximum Cenozoic 
warmth, during the Paleocene and Eocene. In contrast, a Miocene reduction in diversity and abundance of Corbisema correlates with a general cooling of surface waters and an increase in latitudinal thermal gradients. The extinction of the genus occurs in all latitudes during the middle Miocene through a period of rapid cooling of surface waters.

Although Corbisema appears to have favored warmer surface waters, Bukry (1985c) believes that fertility-enhancing conditions, such as nutrient upwelling, may have contributed to high abundances of the genus in some temperate coastal sites (DSDP 415 and 470) and in some high latitude sites. Even though most high latitude sites are characterized by low abundances of Corbisema (e. g., DSDP 173 and 278), it accounts for as much as $58 \%$ of the assemblage in Site 407 between Iceland and Greenland. Thus, high abundances of this genus in the Norwegian Sea are tentatively attributed to enhanced fertility of cool temperate surface waters prior to the middle Miocene cooling which resulted in the global extinction of the genus.

\section{Naviculopsis}

Naviculopsis is a genus that also had its greatest abundance of diversity during the Paleogene. The last significant diversification occurred during the early Miocene, but was followed by an abrupt decline during the late early Miocene. Naviculopsis became extinct at approximately $15 \mathrm{Ma}$ in the lower to middle latitudes (Bukry, 1987), with its last occurrence during the early Miocene in the Norwegian Sea (Ciesielski et al., this volume).

Most species are cosmopolitan and have been noted from the Antarctic to the Norwegian-Greenland Sea. Bukry demonstrated that Naviculopsis and Naviculopsis-like forms occupied a paleotemperature niche similar to the warm- water genus in the tropical Pacific (Bukry, 1985b). Extinction of the genus no doubt was a consequence of the Neogene cooling of surface waters that also eliminated Corbisema. One of the early Miocene species, $N$. quadrata, was shown to be more abundant at higher latitudes than at low latitudes, suggesting some temperature tolerance differences existed among Naviculopsis species (Bukry, 1985b).

\section{Caryocha}

The genus Caryocha includes silicoflagellates with a globular form, numerous apical windows, nearly equant basal spines, and a basal ring equal to or less than the diameter of the apical apparatus (Bukry and Monechi, 1985). Most specimens of this genus in Leg 104 sites are of the species $C$. depressa and $C$. ernestinae. The ranges of both species are restricted to the Miocene and were apparently more abundant in middle to high latitudes. These species rarely became abundant except during the late middle Miocene. Both species were described from the middle Miocene of the Iceland Plateau (Site 348) and Vøring Plateau (Site 338) by Martini and Müller (1976). In some samples from these sites $C$. ernestinae is common to dominant.

The paleoenvironmental affinity of Caryocha is not well-established; however, its increased abundance during the late middle Miocene correlates with a cooling of surface waters based upon other criteria. In Holes $642 \mathrm{C}$ and $643 \mathrm{~A}$, its maximum abundance occurs below an upper-middle Miocene hiatus that marks a major change in the paleoenvironmental conditions of the Norwegian Sea, as will be discussed later. The peak late middle Miocene occurrence also is correlative with the beginning of an increased abundance of Bachmannocena, which had its maximum abundances later during the late Miocene and Pliocene. Because the peak abundance of Caryocha correlates with increasing Bachmannocena, periods of maximum occurrences of Caryocha are interpreted as indicative of increased nutrient supply. In the Norwegian Sea and elsewhere, the demise of Caryocha followed a late middle Miocene to late Miocene increase in the dominance of Bachmannocena and hexagonal Distephanus. Although speculative, it appears reasonable that the brief late middle Miocene acme of Caryocha, and its extinction shortly thereafter, may have been the consequence of ecologic replacement by Bachmannocena.

\section{RESULTS AND DISCUSSION}

\section{SITE 644}

Ninety samples were examined from Hole 644A for their silicoflagellate content (Ciesielski et al., this volume). Silicoflagellates are absent from sediments younger than $0.756 \mathrm{Ma}$ and very rare in Matuyama and upper Gauss Chronozone sediments deposited between 2.64 and $0.76 \mathrm{Ma}$.

Silicoflagellates are common to abundant in Gauss age sediments $(2.85-2.65 \mathrm{Ma})$ from the basal portion of the hole. The assemblage in this interval is dominated by hexagonal Distephanus except for Sample 104-644A-34H-2, 70-72 cm (2.78 Ma), where a significant occurrence of quadrate Distephanus $(\sim 15 \%)$ suggests a brief warming interval. The dominance of hexagonal Distephanus and the occurrence of only one Dictyocha specimen in the upper Gauss sediments, deposited between 2.85 and $2.65 \mathrm{Ma}$, indicate the presence of cold surface waters. Surface waters were most likely $<3^{\circ} \mathrm{C}$, cooler than the $2^{\circ}-6^{\circ} \mathrm{C}$ temperature range of surface waters during the present interglacial. The abundance of silicoflagellates and diatoms argues for normal to enhanced oceanic productivity, in the absence of significant sea ice.

Ciesielski et al. (this volume) found only rare silicoflagellates in sediments younger than $2.65 \mathrm{Ma}$; however, diatoms persisted with a highly variable abundance in sediments deposited between 2.65 Ma and the Matuyama/Brunhes boundary $(0.73$ $\mathrm{Ma}$ ) where there is permanent loss of biogenic opal. The examination of additional samples by Ciesielski (Eldholm, Thiede, Taylor, et al., 1987, p. 628) revealed three other occurrences of silicoflagellates after $2.65 \mathrm{Ma}$. Section 104-644A-21H, CC $(\sim 2.2$ Ma) has frequent hexagonal Distephanus, a few Dictyocha, and abundant diatoms. Samples 104-644A-13H-1, $50 \mathrm{~cm}$ and 644A$12 \mathrm{H}, \mathrm{CC}(\sim 0.98 \mathrm{Ma})$ (core-catcher sample taken from a different interval than that of Ciesielski et al., this volume) contain common hexagonal Distephanus, a few Dictyocha, and common diatoms. These samples are interpreted to represent shortterm minor warming intervals with enhanced productivity that occurred during otherwise dominantly glacial conditions. With the exceptions noted above, silicoflagellates disappeared at 2.65 Ma, 1.9 m.y. prior to diatoms, possibly as a consequence of reduced surface-water fertility.

A permanent reduction in the abundance of diatoms occurred at $\sim 2.65 \mathrm{Ma}$, with frequent fluctuations in their abundance and numerous barren intervals between 2.65 and 0.73 $\mathrm{Ma}$. These fluctuations between diatom occurrences and barren intervals are interpreted to be a consequence of glacial-interglacial variations. Between 2.56 and $1.2 \mathrm{Ma}$, a low and restricted flow of more temperate Atlantic waters into the Norwegian Sea was noted by Henrich (this volume) and Jansen et al. (this volume). Additionally, interglacials were brief and cooler than those of the late Quaternary (Spiegler and Jansen, this volume).

After $0.9 \mathrm{Ma}$, glacial episodes became more severe and interglacials warmer with only brief episodes in a prolonged glacial mode (Jansen et al., this volume). The absence of biogenic opal after $0.76 \mathrm{Ma}$ may be partially attributed to the prevalence of sea ice, limiting productivity of marine algae (e.g., silicoflagellates and diatoms) during the more severe glacials. The absence of diatoms and silicoflagellates in interglacial sediments younger than $0.73 \mathrm{Ma}$ is more difficult to explain because interglacials were inferred to be warmer than those of the late Gauss and Matuyama. Their absence may be the result of postdeposi- 
tional dissolution of interglacial biogenic opal during subsequent glacials.

\section{Site 643 (Figs. 3-5)}

\section{Early Middle Miocene}

The early to middle Miocene assemblage in Hole 643A $(\sim 18.0-13.0 \mathrm{Ma})$ is dominated by quadrate and hexagonal $\mathrm{Di}$ stephanus. Both groups exhibit opposite trends in percentages throughout most of the interval, with a steady increase in the quadrate Distephanus group accompanied by a decline in the hexagonal distephanids. In this interval quadrate Distephanus increases from $\sim 40 \%$ at the base of the hole to a maximum of $90 \%$ at $\sim 14.1$ to $14.2 \mathrm{Ma}$, and then decreases slightly immediately below the middle Miocene hiatus (14.0->13.0 Ma). Hexagonal Distephanus declines from a high of $60 \%$ near the base of the hole to $4 \%$ beneath the middle Miocene disconformity. These trends are interpreted as representing a long period of early to middle Miocene warming of surface waters in the Norwegian Sea. Maximum surface-water temperatures were reached by $14.0 \mathrm{Ma}$. The decline in Distephanus groups between 14.0 and $13.0 \mathrm{Ma}$ appeared to have been caused by an increase in upwelling, which is evidenced by an increase in Bachmannocena at the expense of Distephanus.

The middle Miocene cooling of surface waters is only partially represented beneath the middle upper Miocene hiatus, which eliminated most of the sediment recording the middle to late Miocene cooling. Sample 104-643A-12H-2, 70-72 cm occurs immediately below the upper middle Miocene hiatus and is separated from the remainder of the middle Miocene by a minor hiatus (see Ciesielski, et al., this volume). This sample, the youngest of the middle Miocene section (13.2-12.9 Ma), has a higher percentage of hexagonal Distephanus and Bachmannocena, and a lower percentage of quadrate Distephanus than is evident in the earlier middle Miocene. These characteristics clearly indicate cooler surface waters with large nutrient supply.

Percentages of Bachmannocena are low $(<5 \%)$ in the lower and middle Miocene, except for three intervals: a) during the late middle Miocene (16.8-16.4 Ma, 14\%), b) at approximately the early/middle Miocene boundary (16.1-16.4 Ma, $8 \%$ ), and c) during the middle middle Miocene when the percentage increased from $0 \%$ to $9 \%$ between $\sim 14.2$ and $13.9 \mathrm{Ma}$.

Caryocha accounts for a relatively small percentage of the early to middle Miocene assemblage. Although most percentages range from 0 to $6 \%$, increases in the percentage of Caryocha generally correspond to increases in Bachmannocena. The peak abundance of Caryocha $(11 \%)$ is seen immediately below the middle Miocene disconformity where a $10 \%$ increase in abundance coincides with a $9 \%$ increase in Bachmannocena. These intervals of concurrent higher percentages of Bachmannocena and Caryocha are attributed to increased fertility of surface waters. The fact that these genera show no clear consistent relationship in their covariance with quadrate and hexagonal Distephanus supports an interpretation of enhanced fertility unaccompanied by major rapid fluctuations of temperature.

Dictyocha was a relatively minor component of early and middle Miocene assemblages, with percentages ranging from 0 to $5 \%$. Corbisema was also a minor contributor, less than $5 \%$ of the assemblage, except at the early/middle Miocene boundary where it comprises $9.5 \%$ and corresponds to a peak abundance of Dictyocha. The low percentages of these warm-water genera are similar to those recorded in the lower and middle Miocene of the Southern Ocean (Ciesielski, 1975; Busen and Wise, 1976; Shaw and Ciesielski, 1983; and others). Although more temperate conditions are indicated by the high abundance of quadrate Distephanus during this period, much lower abundances of Corbisema and Dictyocha than at lower latitudes in- dicate a significant latitudinal thermal contrast. Surface-water temperatures were apparently warm enough during the middle Miocene thermal high to allow Corbisema to persist until 13.0 $\mathrm{Ma}$, when it disappeared from lower latitudes. Percentage fluctuations of Corbisema and Dictyocha are too low to be statistically meaningful for inferences on changes in surface-water paleoenvironment.

Naviculopsis occurs near the base of the lower Miocene section where it accounts for 2.5 to $8 \%$ of the assemblages. The region of its occurrence is marked by the highest hexagonal Distephanus values and lowest quadrate Distephanus values. The last occurrence of the genus at this site is interpreted to be coincident with the coolest surface waters of the early Miocene $(\sim 17.9$ 17.6 Ma), and immediately precedes a long early middle Miocene warming trend. The results of Hole 642D suggest that this early Miocene cooling event was probably responsible for the extinction of Naviculopsis in the Norwegian Sea.

\section{Late Miocene}

Seven samples were examined from the upper Miocene of Hole $643 \mathrm{~A}$, ranging in age from $<8.7$ to $6.7 \mathrm{Ma}$. These samples occur above a $\sim 4.0$ m.y. hiatus separating middle and upper Miocene sediments. A marked change in the depositional environment occurred during this 4-m.y. interval as sediment above the hiatus is calcareous nannofossil ooze, the oldest calcareous sediments in Hole 643A. A more complete record of this change in the paleoceanography of the Norwegian Sea is recorded at Site 642 and is presented more fully in the following discussion of that site.

Sample 104-643A-11H-2, 70-72 cm, immediately above a middle upper Miocene hiatus, is dominated by quadrate Distephanus $(71 \%)$. Hexagonal Distephanus is similar to that of the youngest middle Miocene (13\%); however, Bachmannocena accounts for $15 \%$ of the assemblage, which is more than during the preceding early to middle Miocene. Whatever paleoceanographic changes caused the middle upper Miocene hiatus, temperatures and fertility of surface waters were apparently similar when deposition resumed at approximately $8.5 \mathrm{Ma}$. The dominance of quadrate Distephanus and high values of Bachmannocena are indicative of cool to temperate, fertile surface waters.

Between 8.5 and $8.0 \mathrm{Ma}$, Bachmannocena obtained its greatest Neogene abundance ( $95 \%)$; quadrate Distephanus decreased and hexagonal Distephanus increased slightly prior to the almost total dominance of Bachmannocena in Sample 104-643A$10 \mathrm{H}-5,68-70 \mathrm{~cm}$. The abundance of silicoflagellate fragments in this latter sample immediately precedes an overlying barren interval deposited during Chrons C4AN and C4R. This sample was probably deposited during a period of upwelling at the onset of a major late Miocene cooling evident in samples above.

Samples 104-643A-10H-2, 68-7O cm and -643A-9H-5, 69-71 $\mathrm{cm}$ were deposited between $\sim 8.0$ and $7.5 \mathrm{Ma}$, and are barren of silicoflagellates; they contain only sparse assemblages of diatoms. This interval closely corresponds to the first occurrence of the cold-water foraminifer, Neogloboquadrina pachyderma. The period appears to have been one of increased cooling of surface waters, which was accompanied by increased silica dissolution.

Above the upper Miocene barren interval (Samples 104-643A$9 \mathrm{H}-2,70-72 \mathrm{~cm}$ and $-643 \mathrm{~A}-8 \mathrm{H}-5,67-69 \mathrm{~cm}$ ), fragmented silicoflagellates outnumber whole specimens in these samples, which are probably only slightly younger than $7.41 \mathrm{Ma}$. The assemblage of silicoflagellates is unlike any from the preceding Miocene; it is dominated by hexagonal Distephanus (70\%) and again contains a large percentage of Bachmannocena (27-30\%). The warm to temperate surface-water indicators are absent (Dictyocha) or sparse (quadrate Distephanus, $<5 \%$ ), and dissolution-resistant species predominate. The high proportion of hex- 


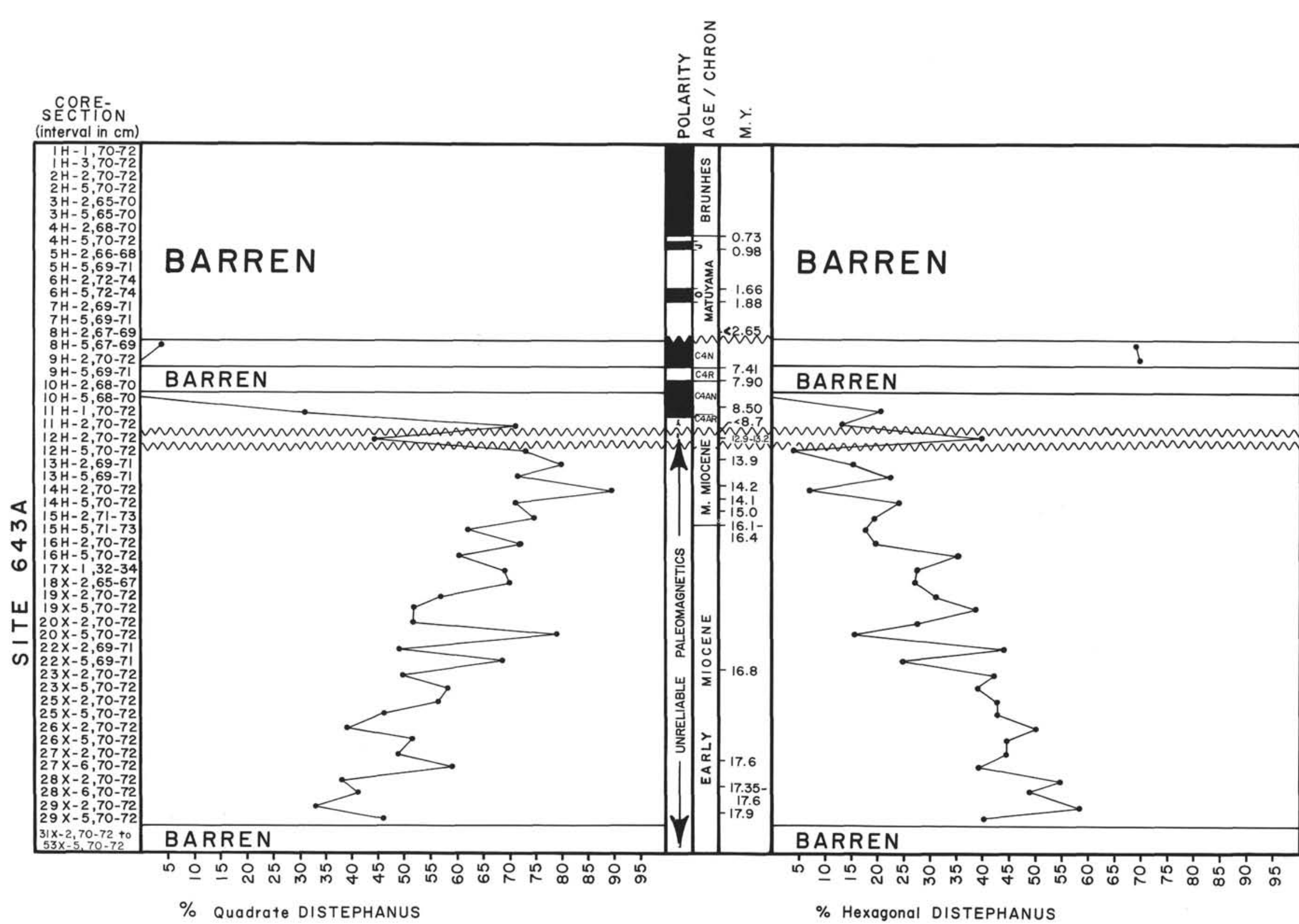

Figure 3. Fluctuations in quadrate Distephanus (left) and hexagonal Distephanus (right) as a percentage of the total silicoflagellate assemblage in the Neogene of Hole 643A. Selected absolute ages from Table 1. 


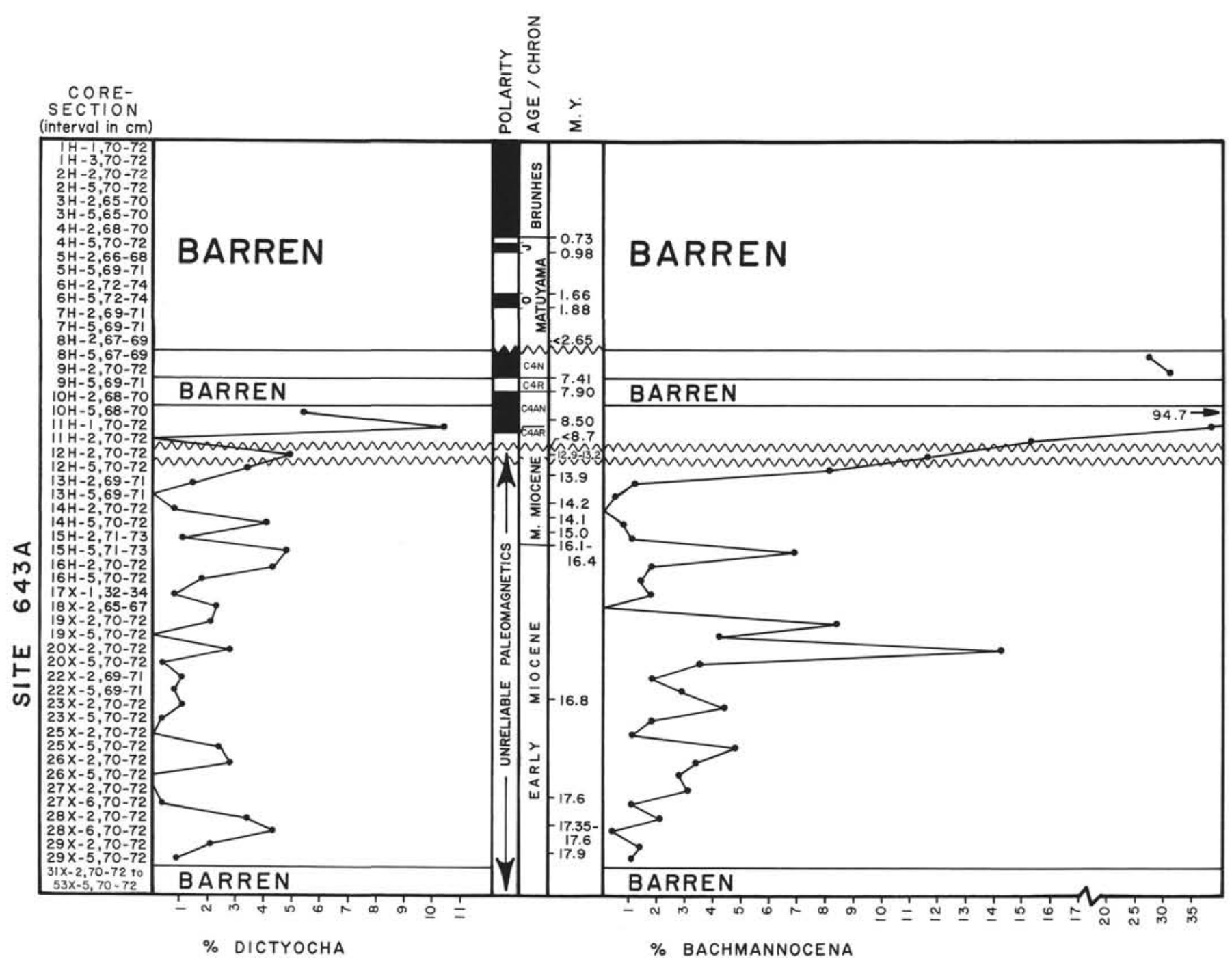

Figure 4. Fluctuations in Dictyocha (left) and Bachmannocena (right) as a percentage of the total silicoflagellate assemblage in the Neogene of Hole 643A. Selected absolute ages from Table 1.

agonal Distephanus and Bachmannocena are indicative of cold surface waters with high fertility.

\section{Pliocene-Quaternary}

Above the disconformity that separates upper Miocene from uppermost Pliocene-Quaternary, sediments are barren of silicoflagellates. According to the biostratigraphy and magnetostratigraphy, this barren interval represents the lower Matuyama through Brunhes Chronozones ( $<2.42 \mathrm{Ma}$ to Present). Sediments of similar age from Sites 642 and 644 are also barren. Paleoceanographic conditions at Site 643 were apparently similar to those discussed for Site 644, and indicate the dominance of glacial conditions along the entire Leg 104 transect in the Norwegian Current.

\section{Site 642 (Figs. 6-8)}

\section{Early to Middle Miocene}

The basal two samples of the lower Miocene section in Hole 642D (Samples 104-642D-10X-2, 110-113 cm and 642D-10X-5, $110-113 \mathrm{~cm})$ are dominated by quadrate Distephanus, Corbisema, and have the lowest percentage of hexagonal Distephanus of the lower Miocene. These characteristics, in particular the high percentage of Corbisema $(20-33 \%)$, indicate temperate conditions and high surface-water fertility.

A pronounced early Miocene cooling event is evident between Samples 104-642D-10X-2, 110-113 cm and -642D-6X-2, $125-127 \mathrm{~cm}$, where hexagonal Distephanus increases from less than $10 \%$ to $60 \%$ of the assemblage. During this time the percentage of Corbisema decreased from $33 \%$ to $0 \%$; thereafter, Corbisema never accounted for more than $1 \%$ of the assemblage. The most abrupt portion of this cooling appears between Samples 104-642D-6X-4, 115-117 cm and -642D-6X-2, 125-127 $\mathrm{cm}$, where hexagonal Distephanus increases from $21 \%$ to $60 \%$. Simultaneous with this increase are abrupt declines in all warmer water indicators, Corbisema, Naviculopsis, and quadrate Distephanus. This peak occurrence of hexagonal Distephanus correlates closely with its counterpart in Hole $643 \mathrm{~A}$ where it reaches $58 \%$. In Holes 642D and 643A the early Miocene cooling maxima resulted in the disappearance of Naviculopsis. The age of this inferred cooling maximum is estimated to have occurred slightly prior to $17.6 \mathrm{Ma}$.

The remaining lower Miocene section above the cooling maximum indicates that the cooling was of short duration. The percentage of hexagonal Distephanus abruptly declined (60-30\%), and the more temperate quadrate Distephanus abruptly increased 


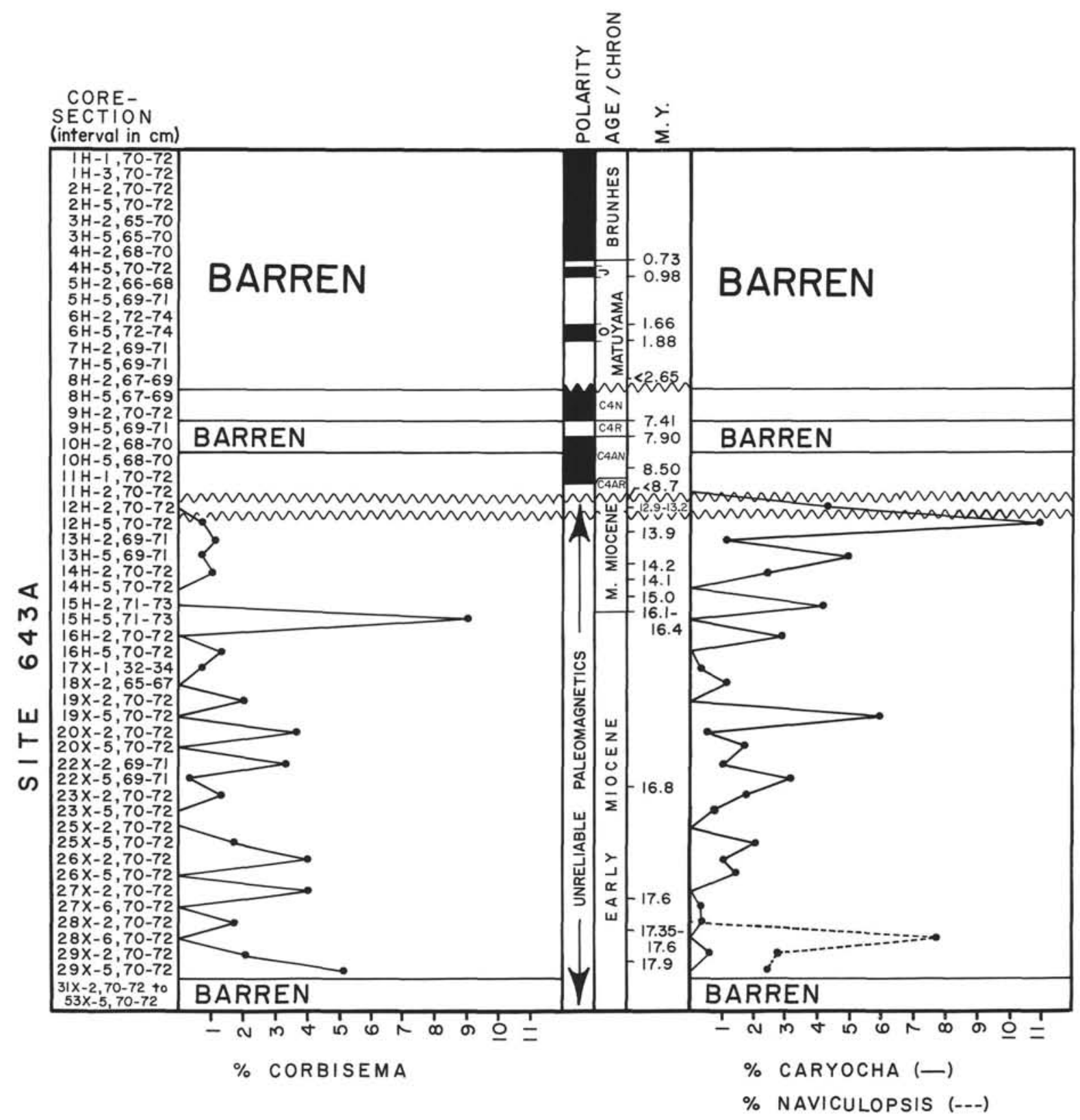

Figure 5. Fluctuations in Corbisema (left), Naviculopsis (right, dashed line), and Caryocha (right, solid line) as a percentage of the total silicoflagellate assemblage in the Neogene of Holes 643A. Selected absolute ages from Table 1.

$(39-65 \%)$ prior to $17.3 \mathrm{Ma}$ in both holes. After a brief period of stable conditions bracketing $17.3 \mathrm{Ma}$, a continuation of the warming trend occurred until slightly after $16.8 \mathrm{Ma}$. This period is characterized by a further increase in the percentage of the more temperate quadrate Distephanus (60-87\%), and a decrease in the cooler water hexagonal Distephanus group (31-11\%). Between 16.8 and $16.1 \mathrm{Ma}$ a continuation of the early Miocene thermal high into the early late Miocene is inferred from high quadrate Distephanus and low hexagonal Distephanus percentages. This signal of overall warmth is overprinted by broad fluctuations in the ratios of quadrate Distephanus and hexagonal Distephanus, suggesting unstable surface-water conditions. Hole $643 \mathrm{~A}$ contains a more detailed record of this latter interval because of exceptionally high sedimentation rates. A major difference between Holes $643 \mathrm{~A}$ and $642 \mathrm{C}$, D is that peak abun- dances of Bachmannocena are much less at Holes 642C, D; that lower value, coupled with a lower sedimentation rate at Site 642C, D suggests lower fertility than at Site 643A.

Both records from Holes $643 \mathrm{~A}$ and $642 \mathrm{C}$ exhibit a prolongation of the thermal high in the middle Miocene between 16.1 and 13.9 Ma. Site 642 became a zone of upwelling at $\sim 13.7 \mathrm{Ma}$ as indicated by major increases in Caryocha (to $31 \%$ ) and Bachmannocena (to $19 \%$ ) abundances between this datum and the middle upper Miocene hiatus (>12.9 Ma). Increases in these genera appear to have been at the expense of quadrate Distephanus which declined from $83 \%$ to $39-55 \%$. Continued low values of hexagonal Distephanus during this period suggest no major decline in temperatures accompanying this period of upwelling. This conclusion is supported by an increase in Dictyocha abundance. A similar and synchronous record of middle Miocene 


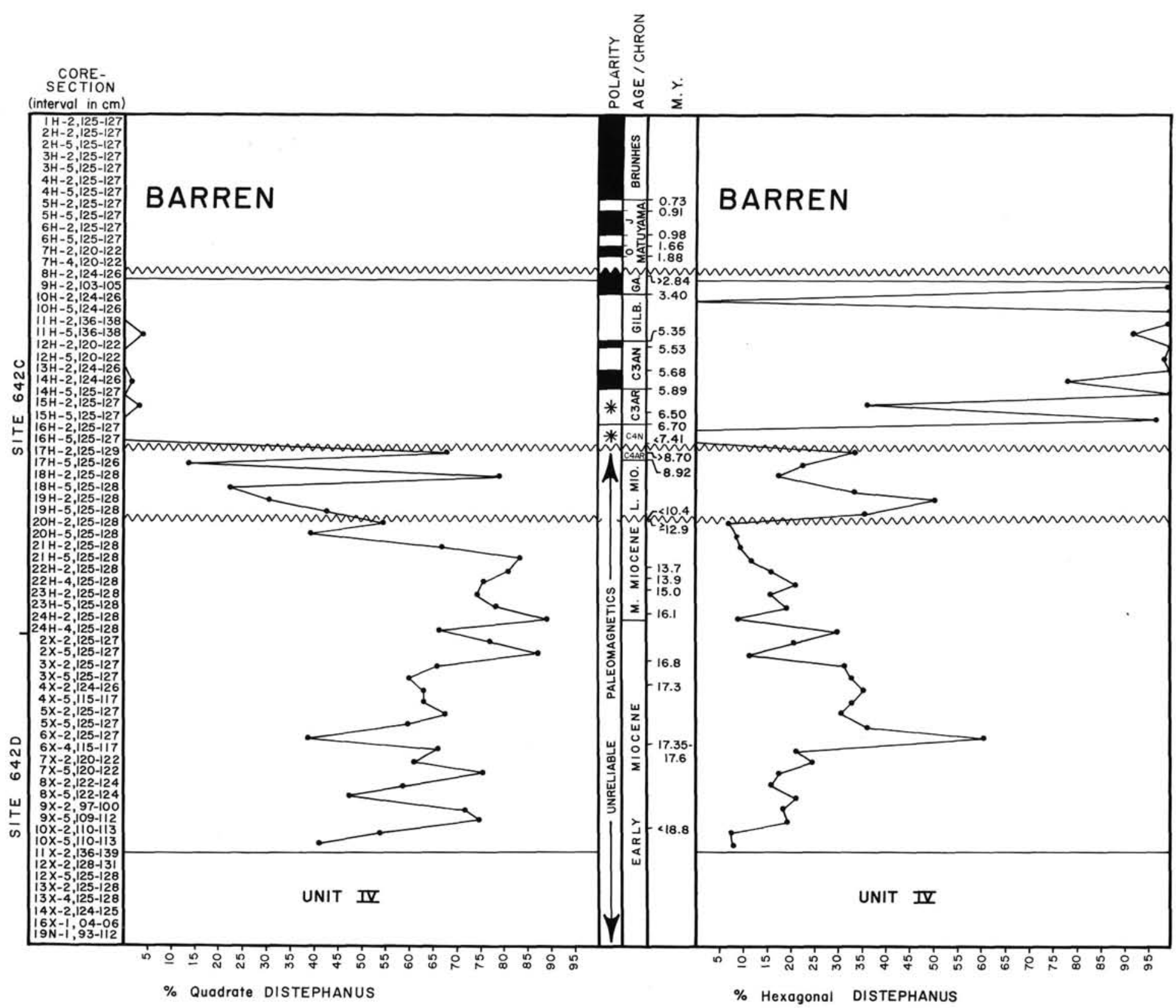

Figure 6. Fluctuations in quadrate Distephanus (left) and hexagonal Distephanus (right) as a percentage of the total silicoflagellate assemblage in the Neogene of Holes 642C and 642D. Selected 


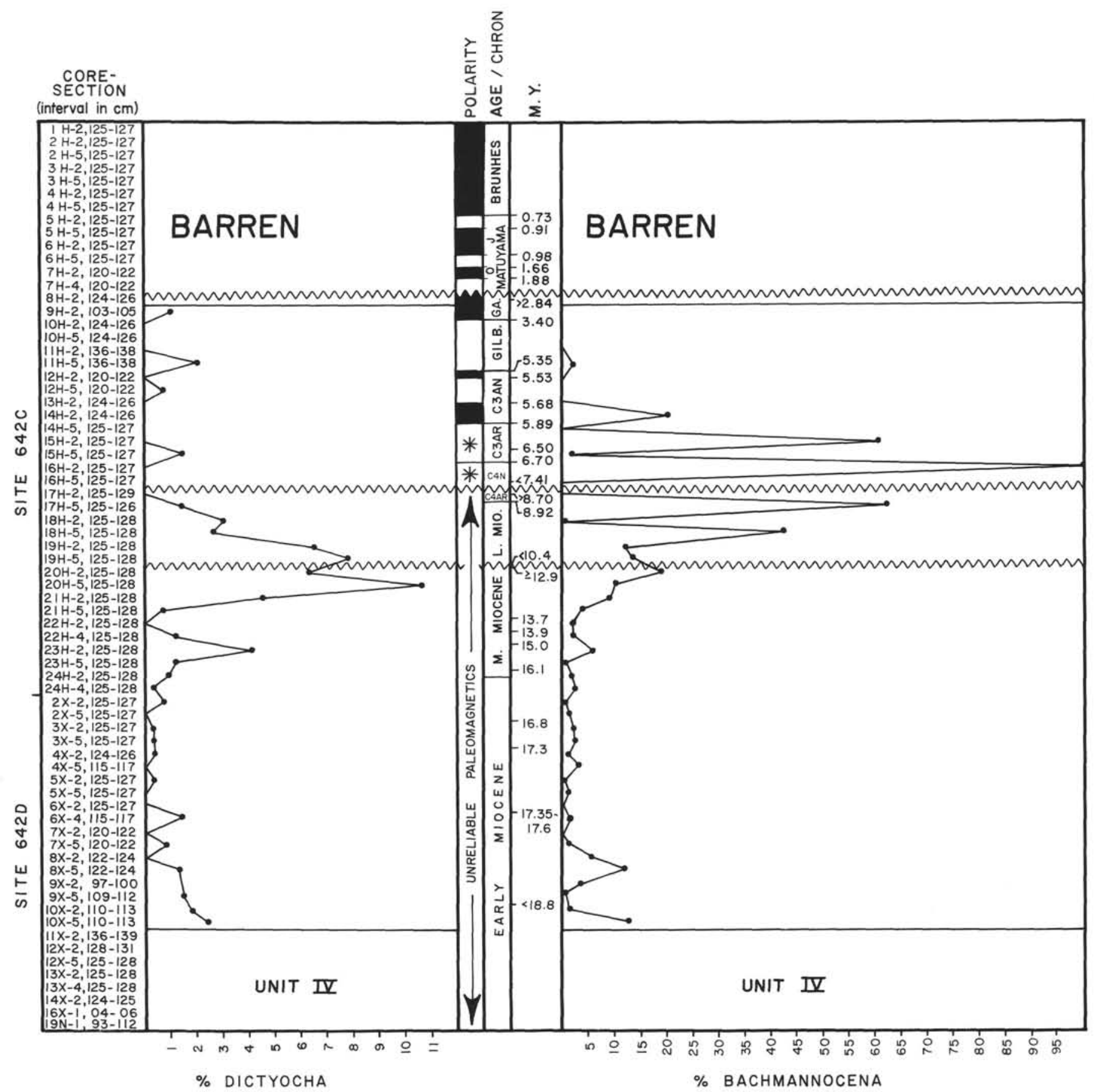

Figure 7. Fluctuations in Dictyocha (left) and Bachmannocena (right) as a percentage of the total silicoflagellate assemblage in the Neogene of Holes $642 \mathrm{C}$ and 642D. Selected absolute ages from Table 2. *Paleomagnetic polarity boundaries for these intervals cannot be accurately represented in this space; consult Eldholm, Thiede, Taylor, et al., 1987. Unit IV overlies the Eocene volcanic sequence and consists of volcanoclastic muds, sandy muds, and sands with downhole-displaced Miocene silicoflagellates (see Ciesielski et al., this volume).

upwelling is found at Site 643 where it appears as a precursor to a period of nondeposition or erosion that formed a middle upper Miocene hiatus at these sites.

On the basis of a comparison of assemblages above and below this hiatus, it appears that the single largest change in the Neogene paleoenvironment of the Norwegian Sea occurred between 13 and $10 \mathrm{Ma}$ and is represented only by a middle upper Miocene disconformity. One clear consequence of this change was a deepening of the carbonate compensation depth (CCD) which resulted in the initial significant deposition of calcareous sediments on the Vøring Plateau and a permanent decrease in biogenic opal sediment accumulation (Eldholm, Thiede, Taylor, et al., 1987). These changes in sedimentation apparently began during the late middle Miocene as sediment immediately below the late middle Miocene hiatus contains some carbonate $(\sim 13.5$ $\mathrm{Ma})$. Further deepening of the CCD occurred during the time represented by the middle late Miocene hiatus, as sediments immediately above it have significant amounts of carbonate at 


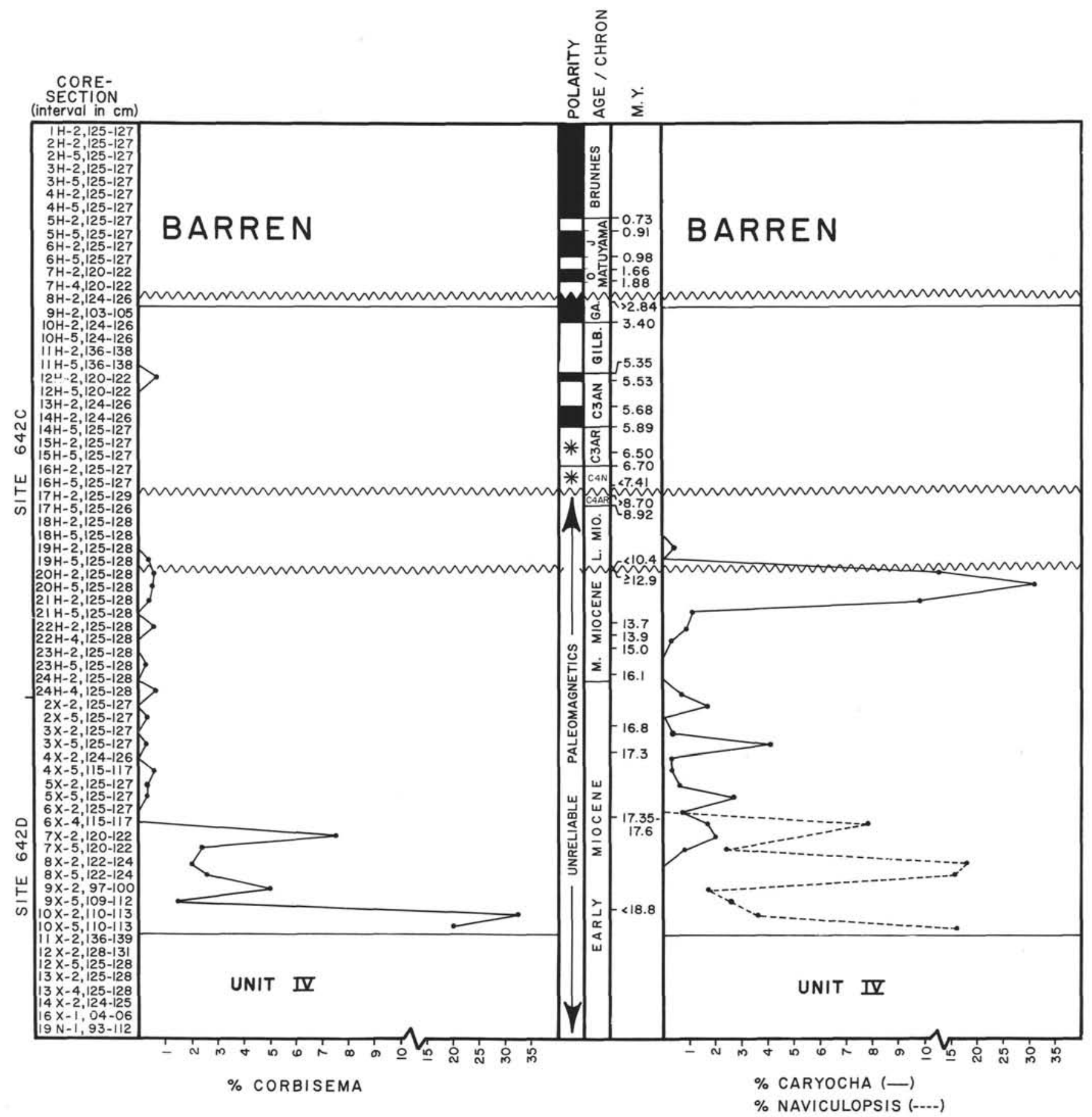

Figure 8. Fluctuations in Corbisema (left), Naviculopsis (right, dashed line), and Caryocha (right, solid line) as a percentage of the total silicoflagellate assemblage in the Neogene of Holes $642 \mathrm{C}$ and $642 \mathrm{D}$. Selected absolute ages from Table 2. *Paleomagnetic polarity boundaries for these intervals cannot be accurately represented in this space; consult Eldholm, Thiede, Taylor, et., 1987. Unit IV overlies the Eocene volcanic sequence and consists of volcanoclastic muds, sandy muds, and sands with downhole-displaced Miocene silicoflagellates (see Ciesielski et al., this volume).

both sites. The shift to increased carbonate sedimentation began by $13.5 \mathrm{Ma}$, however, most of the change in sedimentary regeme occurred between 13.0 and 10.0 Ma.

\section{Late Miocene}

A hiatus separates middle and upper Miocene sediments in Hole $642 \mathrm{C}$, representing a minimum of $3.0 \mathrm{~m}$.y. Subsequent samples between Samples 104-642C-19C-2, 125-128 cm and $642 \mathrm{C}-17 \mathrm{H}-2,125-129 \mathrm{~cm}$ represent the early late Miocene $(\sim 10.0-$
10.4 to $8.7-8.5 \mathrm{Ma}$ ). This interval is characterized by a decline in Dictyocha (8-0\%), highly variable quadrate Distephanus (14-79\%), and higher hexagonal Distephanus values (18-50\%) than during the preceding middle Miocene. Bachmannocena percentages are also highly variable $(0-63 \%)$ with two major peak occurrences much higher $(42 \%$ and $63 \%)$ than any values from the lower to middle Miocene.

The lower upper Miocene assemblages indicate much different conditions in the Norwegian Sea than during the early to middle 
Miocene. Surface-water temperatures were significantly cooler than the preceding Miocene, but warmer than the PlioceneQuaternary. The results of the limited number of samples from this interval suggest highly variable conditions, exemplified by large variations in the percentages of the taxonomic groups.

\section{Pliocene-Quaternary}

Five samples were examined from the Gilbert-lower Gauss Chronozones, Samples 104-642C-11H-2, 136-148 cm to $-642 \mathrm{C}$ $8 \mathrm{H}-2,124-126 \mathrm{~cm}$. These samples are characterized by the almost total dominance of hexagonal Distephanus (90-100\%). Dictyocha and quadrate Distephanus account for $7 \%$ or less of the assemblage. These assemblages are indicative of subpolar conditions with surface-water temperatures between $1^{\circ}$ and $4^{\circ} \mathrm{C}$. Bachmannocena is absent; however, the genus has not been noted in high latitudes after the earliest Pliocene (Shaw and Ciesielski, 1983), and its absence cannot be interpreted as due to a lack of surface-water fertility.

Sample $104-642 \mathrm{C}-10 \mathrm{H}-2,124-126 \mathrm{~cm}$ is a late Gilbert chron nannofossil ooze barren of silicoflagellates. Sample 104-642C$9 \mathrm{H}-2,103-105 \mathrm{~cm}$ occurs in the basal Gauss Chron, only $1.5 \mathrm{~m}$ above the Gilbert/Gauss boundary. While also being a nannofossil ooze, this sample contains a sparse silicoflagellate assemblage consisting almost entirely $(99 \%)$ of hexagonal Distephanus indicative of polar surface waters.

A hiatus separates the lower Gauss of Sample 104-642C-9H2, 103-105 cm from lower Matuyama Chronozone sediments in Sample 104-642C-8H-2, 124-126 cm. Sediments above this hiatus are glacial and interglacial muds, sandy muds, and are barren of silicoflagellates.

\section{CONCLUSIONS}

1. A pronounced early Miocene cooling event of short duration occurred at approximately 18.0 to $17.5 \mathrm{Ma}$, as indicated by an increase in hexagonal Distephanus and a decrease in quadrate Distephanus. The last occurrences of Naviculopsis in Holes $642 \mathrm{D}$ and $643 \mathrm{~A}$ are coincident with the peak of this cooling that also caused a permanent decrease in the abundance of Corbisema.

2. Following the early Miocene cooling event was a long period of increasing surface-water temperatures leading to a thermal high in the middle Miocene at $\sim 14.0 \mathrm{Ma}$.

3. Increased periods of upwelling during this thermal high are evident in peak abundances in Bachmannocena and/or $\mathrm{Ca}$ ryocha between 16.8 and $16.1 \mathrm{Ma}$ and from 14.0 to $13.0 \mathrm{Ma}$.

4. Although the early middle Miocene was relatively warm, sufficient latitudinal thermal contrast existed between the Norwegian Sea and lower latitude regions to reduce abundant Corbisema and Dictyocha in these sites relative to the lower latitudes.

5. Sea-surface temperatures were sufficiently high for Corbisema to persist in the Norwegian Sea until 13.0 Ma, approximately the same time it became extinct at lower latitudes.

6. A period of nondeposition or erosion formed a 4.5-m.y. hiatus at Site $643(\sim 13.0-8.5 \mathrm{Ma})$ and a 3.0-m.y. hiatus at Site $642(\sim 13.0-10.0 \mathrm{Ma})$ bracketing the middle upper Miocene.

7. A deepening of the $C C D$ began by 13.5 Ma that resulted in major cycles of late Miocene to Pliocene carbonate deposition in the Norwegian Current. The most significant deepening of the CCD occurred prior to the resumption of deposition after formation of the middle late Miocene hiatus, between 13.0 and $10.0 \mathrm{Ma}$.

8. The earliest late Miocene ( 10.0-9.0 Ma, Hole $642 \mathrm{C})$ was distinctly cooler than the preceding middle Miocene and significantly warmer than the latest Miocene. Fertility was at times high.
9. A major plunge in surface-water temperatures occurred between 8.5 and $7.4 \mathrm{Ma}$, which was accompanied by significant upwelling, biogenic silica dissolution, and an increase in benthic current strength. This event produced a zone of barren-to-poorly preserved biosiliceous sediments at Site 643 and a disconformity at Site 642.

10. The latest Miocene $(<7.41-5.35 \mathrm{Ma}$, Hole $642 \mathrm{C})$ is characterized by the dominance of hexagonal Distephanus, indicative of cold surface waters probably less than $4^{\circ} \mathrm{C}$. High sedimentation rates and intervals enriched in Bachmannocena suggest high fertility. Periods of reduced productivity and/or strong opal dissolution were frequent.

11. Gilbert-lower Gauss sediments ( 5.35 to $>2.84 \mathrm{Ma}$ ) were only recovered from Hole $642 \mathrm{C}$. Dominance of hexagonal $\mathrm{Di}$ stephanus $(90-100 \%)$ is indicative of cold surface waters of less than $4^{\circ} \mathrm{C}$.

12. A disconformity is present between the lower Gauss and lower Matuyama Chronozones of Hole 642C, and no Gauss age sediments occur in Hole 643. During the Gauss Chron, strong benthic currents prevailed on the outer Vøring Plateau, while the landward Site 644 became a major depositional center of glacial sedimentation.

13. Between 2.85 and $2.65 \mathrm{Ma}$, surface waters were most likely $<3^{\circ} \mathrm{C}$ cooler than the $2^{\circ}-6^{\circ} \mathrm{C}$ temperature range of surface waters during the present interglacial. The abundance of silicoflagellates and diatoms argues for normal to enhanced oceanic productivity in the absence of significant sea ice.

14. The last consistent occurrence of silicoflagellates in the Norwegian Sea occurred during the late Gauss $(\sim 2.65 \mathrm{Ma})$, simultaneously with a permanent reduction in the abundance of diatoms. The near-total absence of silicoflagellates during the latest Gauss-Matuyama Chron (2.64-0.76 Ma) is interpreted to be the result of decreased fertility of surface waters.

15. Glacial-interglacial cycles are evident between 2.64 and $0.76 \mathrm{Ma}$ as variations in the abundance of diatoms. Several glacial intervals are evident as intervals barren of diatoms and silicoflagellates, indicative of the presence of permanent pack ice in the Norwegian Sea. The most prominent interglacials during this period occurred at $\sim 2.2$ and $0.98 \mathrm{Ma}$, the sole occurrences of significant numbers of silicoflagellates after $2.65 \mathrm{Ma}$.

16. Biogenic opal is absent from latest Matuyama-Brunhes Chronozone sediments (0.76-Present). This absence is attributed to both a dominance of a glacial regime with extensive ice cover during glacials and postdepositional dissolution of interglacial biogenic opal during subsequent glacials.

\section{ACKNOWLEDGMENTS}

The National Science Foundation and the Joint Oceanographic Institutions, Inc. are thanked for the sponsorship of the shipboard participation of Paul F. Ciesielski on the Ocean Drilling Program Leg 104. These same institutions are also thanked for their postcruise financial support of this research through the Texas A\&M Research Foundation/ United States Science Program award No. 76056 to him.

Kozo Takahashi and Kevin McKartney are thanked for their critical review of the manuscript.

\section{REFERENCES}

Barron, J. A., 1985a. Late Eocene to Holocene diatom biostratigraphy of the equatorial Pacific Ocean, Deep Sea Drilling Project Leg 85. In Mayer, L., Thayer, F., et al., Init. Repts. DSDP, 85: Washington (U. S. Govt. Printing Office), 413-456.

1985b. Miocene to Holocene planktonic diatoms. In Bolli, H. M., Saunders, J. B., and Perch-Nielsen, K. (Eds.), Plankton Stratigraphy. Cambridge, U.K. (Cambridge University Press), 811846.

Barron, J. A., Keller, G., and Dunn, D. A., 1985. A multiple microfossil biochronology for the Miocene. Geol. Soc. Am. Mem., 163: 2136. 
Berggren, W. A., Kent, D. V., Flynn, J. J., and Van Couvering, J. A., 1985. Cenozoic geochronology. Geol. Soc. Am. Bull., 96: 14071418.

Bukry, D., 1981a. Silicoflagellate stratigraphy of offshore California and Baja California, Deep Sea Drilling Project Leg 63. In Yeats, R. S., Haq, B. U., et al., Init. Repts. DSDP, 63: Washington (U. S. Govt. Printing Office), 539-557.

$1981 \mathrm{~b}$. Synthesis of silicoflagellate stratigraphy for Maestrichtian to Quaternary marine sediment. Soc. Econ. Paleontol. Mineral. Spec. Publ., 32: 433-444.

1983. Upper Cenozoic silicoflagellates from offshore Ecuador, Deep Sea Drilling Project Site 504. In Cann, J. R., Langseth, M. G., et al., Init. Repts. DSDP, 69: Washington (U.S. Govt. Printing Office), 321-342.

1985a. Cenozoic silicoflagellates from Rockall Plateau, Deep Sea Drilling Project Leg 81. In Roberts, D. G., Schnitker, D., et al., Init. Repts. DSDP, 81: Washington (U.S. Govt. Printing Office), 547-563.

1985b. Tropical Pacific silicoflagellate zonation and paleotemperature trends of the Late Cenozoic. In Ross, D. A., Neprochnov, Y. P., et al., Init. Repts. DSDP, 85: Washington (U.S. Govt. Printing Office), 477-497.

1985c. Late Cenozoic silicoflagellates from the northwest $\mathrm{Pa}$ cific, Deep Sea Drilling Project Leg 86: paleotemperature trends and texture classification. In Heath, G. R., Burckle, L. H., et al., Init. Repts. DSDP, 86: Washington (U.S. Govt. Printing Office), 367396.

1986. Miocene silicoflagellates from the Chatham Rise, Deep Sea Drilling Project Site 594. In Kennett, J. P., von der Borch, C. C., et al., Init. Repts. DSDP, 90, Pt. 2: Washington (U.S. Govt. Printing Office), 925-937.

1987. Eocene siliceous and calcareous phytoplankton, Deep Sea Drilling Project Leg 95. In Poag, C. W., Watts, A. B., et al., Init. Repts. DSDP, 95: Washington (U.S. Govt. Printing Office), 395-415.

Bukry, D., and Monechi, S., 1985. Late Cenozoic silicoflagellates from the Northwest Pacific, Deep Sea Drilling Project Leg 86. Paleotemperature trends and texture classification. In Heath, G. R., Burckle, L. H., et al., Init. Repts. DSDP, 86: Washington (U.S. Govt. Printing Office), 367-397.

Burckle, L. H., 1978. Early Miocene to Pliocene diatom datum levels for the equatorial Pacific. Proc. Second Working Group Mtg., Biostratig. Datum Planes Pacific Neogene, IGCP Project 114 (Bandung, Indonesia, May 30-June 1, 1977). Spec. Publ., Geol. Res. Dev. Ctr., 1: $25-44$.

Burckle, L. H., Keigwin, L. D., and Opdyke, N. D., 1982. Middle and late Miocene stable isotopic stratigraphy: correlation to the paleomagnetic reversal record. Micropaleontology, 28: 329-334.

Busen, K., and Wise, S. W., Jr., 1976. Silicoflagellate stratigraphy, Deep Sea Drilling Project, Leg 36. In Barker, P., Dalziel, I.W.D., et al., Init. Repts. DSDP, 36: Washington (U.S. Govt. Printing Office), 697-743.

Ciesielski, P. F., 1974. Silicoflagellate paleotemperature curve for the Southern Ocean. Antarctic J. of the U.S., 9: 269-270.
1975. Biostratigraphy and paleoecology of Neogene and Oligocene silicoflagellates from cores recovered during Antarctic Leg 28, Deep Sea Drilling Project. In Hayes, D. E., Frakes, L. A., et al., Init. Repts. DSDP, 28: Washington (U.S. Govt. Printing Office), 625-691.

1983. The Neogene and Quaternary diatom biostratigraphy of sub-Antarctic sediments, Deep Sea Drilling Project Leg 71. In Ludwig, W. J., Krasheninnikov, V. A., et al., Init. Repts. DSDP, 71, Pt. 2: Washington (U.S. Govt. Printing Office), 635-665.

Ciesielski, P. F., and Weaver, F. M., 1974. Early Pliocene temperature changes in the Antarctic Seas. Geology. 2: 511-515.

Eldholm, O., Thiede, J., Taylor, E., 1987. Evolution of the Norwegian continental margin: background and objectives. In Eldholm, O., Thiede, J., Taylor, E., et al., Proc. ODP, Init. Repts., 104: College Station, TX (Ocean Drilling Program), 5-25.

Eldholm O., Thiede, J., Taylor, E., et al. (1987). Proc. ODP, Init. Repts., 104: College Station, TX (Ocean Drilling Program).

Gemeinhardt, E., 1934. Die Silicoflagellaten des südatlantischen Ozeans. Wiss. Ergebnisse der deutschen Atlantischen Expedition auf den Forschungs-und Vermessungsschiff; "Meteor" 1925-1927, 12: 274312.

Kellogg, T. B., 1975. Late Quaternary climatic changes in the Norwegian and Greenland Seas. In Weller, G., and Bowling, J. A. (Eds.), Climate of the Arctic. Proc. 24th Alaska Sci. Conf., Geophys. Inst. Univ. Alaska, 3-36.

1976. Late Quaternary climatic changes: Evidence from deep-sea cores of Norwegian and Greenland Seas. Geol. Soc. Am. Mem., 145: 77-110.

Mandra, Y. T., 1969. Silicoflagellates: a new tool for the study of Tertiary climates. Antarctic J. of the U. S., 4: 172-174.

Martini, E., 1971. Neogene silicoflagellates from the equatorial Pacific. In Winterer, E. L., Riedel, W. R., et al., Init. Repts. DSDP, 7, Pt. 2: Washington (U.S. Govt. Printing Office), 1695-1708.

Martini, E., and Müller, C., 1976. Eocene to Pleistocene silicoflagellates from the Norwegian-Greenland Sea (DSDP Leg 38). In Talwani, M., Udintsev, G., et al., Init. Repts. DSDP, 38: Washington (U.S. Govt. Printing Office), 857-895.

Poelchau, H. S., 1974. Holocene silicoflagellates of the North Pacific: their distribution and use for paleotemperature determination $[\mathrm{Ph}$. D. Thesis]. University of California, San Diego.

Shaw, C. A., and Ciesielski, P. F., 1983. Silicoflagellate biostratigraphy of middle Miocene to Holocene subantarctic sediments recovered by Deep Sea Drilling Project Leg 71. In Ludwig, W. J., Krasheninnikov, V. A., et al., Init. Repts. DSDP, 71: Washington (U.S. Govt. Printing Office), 687-737.

Takahashi, K., 1987. Seasonal fluxes of silicoflagellates and Actiniscus in the subarctic Pacific during 1982-1984. J. Marine Res., 45: 397425.

Talwani, M., and Udintsev, G., et al., 1976. Init. Repts. DSDP, 38: Washington (U.S. Govt. Printing Office).

Date of initial receipt: 1 December 1987

Date of acceptance: 10 May 1988 Ms 104B-166

Ms 104B-166 